\title{
Nitrite oxidation in the Namibian oxygen minimum zone
}

\author{
Jessika Füssel, Phyllis Lam, Gaute Lavik, Marlene M Jensen ${ }^{1}$, Moritz Holtappels, \\ Marcel Günter and Marcel MM Kuypers \\ Department of Biogeochemistry, Max Planck Institute for Marine Microbiology, Bremen, Germany
}

\begin{abstract}
Nitrite oxidation is the second step of nitrification. It is the primary source of oceanic nitrate, the predominant form of bioavailable nitrogen in the ocean. Despite its obvious importance, nitrite oxidation has rarely been investigated in marine settings. We determined nitrite oxidation rates directly in ${ }^{15} \mathrm{~N}$-incubation experiments and compared the rates with those of nitrate reduction to nitrite, ammonia oxidation, anammox, denitrification, as well as dissimilatory nitrate/nitrite reduction to ammonium in the Namibian oxygen minimum zone (OMZ). Nitrite oxidation ( $\left.\leqslant 372 \mathrm{nM} \mathrm{NO}_{2}^{-} \mathrm{d}^{-1}\right)$ was detected throughout the $\mathrm{OMZ}$ even when in situ oxygen concentrations were low to non-detectable. Nitrite oxidation rates often exceeded ammonia oxidation rates, whereas nitrate reduction served as an alternative and significant source of nitrite. Nitrite oxidation and anammox co-occurred in these oxygen-deficient waters, suggesting that nitrite-oxidizing bacteria (NOB) likely compete with anammox bacteria for nitrite when substrate availability became low. Among all of the known NOB genera targeted via catalyzed reporter deposition fluorescence in situ hybridization, only Nitrospina and Nitrococcus were detectable in the Namibian OMZ samples investigated. These NOB were abundant throughout the $\mathrm{OMZ}$ and contributed up to $\sim 9 \%$ of total microbial community. Our combined results reveal that a considerable fraction of the recently recycled nitrogen or reduced $\mathrm{NO}_{3}^{-}$was re-oxidized back to $\mathrm{NO}_{3}^{-}$via nitrite oxidation, instead of being lost from the system through the anammox or denitrification pathways.

The ISME Journal (2012) 6, 1200-1209; doi:10.1038/ismej.2011.178; published online 15 December 2011 Subject Category: geomicrobiology and microbial contributions to geochemical cycles

Keywords: Benguela upwelling; nitrite oxidation; Nitrococcus; Nitrospina; nitrification; oxygen minimum zone
\end{abstract}

\section{Introduction}

Nitrogen is the limiting element for primary production in many parts of the ocean, and its availability is therefore closely coupled to the biological sequestration of atmospheric carbon dioxide and the oceanic carbon cycle (Gruber, 2004). Nitrate $\left(\mathrm{NO}_{3}^{-}\right)$ is the most abundant form of bioavailable inorganic nitrogen $\left(\mathrm{NH}_{4}^{+}, \mathrm{NO}_{2}^{-}, \mathrm{NO}_{3}^{-}\right)$in the ocean. It is formed via nitrification, a biologically mediated two-step process comprising the oxidation of ammonia $\left(\mathrm{NH}_{3}\right)$ to nitrite $\left(\mathrm{NO}_{2}^{-}\right)$, and that of $\mathrm{NO}_{2}^{-}$to $\mathrm{NO}_{3}^{-}$, each of which is catalyzed by distinct groups of microorganisms. The majority of oceanic $\mathrm{NO}_{3}^{-}$is locked up in the deep sea, where it is no longer assimilated by phytoplankton and thus accumulates to high concentrations of $20-50 \mu \mathrm{M}$. In the surface ocean, $\mathrm{NO}_{3}^{-}$ is usually depleted. Only in regions with strong diapycnal mixing or upwelling, deep-sea $\mathrm{NO}_{3}^{-}$

Correspondence: J Füssel, Department of Biogeochemistry, Max Planck Institute for Marine Microbiology, Celsiusstrasse 1, Bremen 28359, Germany.

E-mail: jfuessel@mpi-bremen.de

${ }^{1}$ Current address: Nordic Center of Earth Evolution and Institute of Biology, University of Southern Denmark, Odense, Denmark.

Received 30 March 2011; revised 30 September 2011; accepted 4 November 2011; published online 15 December 2011 re-enters the euphotic zone and stimulates surface primary production. This in turn results in enhanced sinking of organic matter and subsequent remineralization that releases ammonium $\left(\mathrm{NH}_{4}^{+}\right)$, especially around the base of the euphotic zone. Consequently, nitrification is stimulated therein and $\mathrm{NH}_{4}^{+}$is recycled back to $\mathrm{NO}_{3}^{-}$.

In certain highly productive regions, respiration of organic matter below the euphotic zone can be so intense that oxygen minimum zones (OMZs) develop. Upon oxygen depletion in the OMZs, $\mathrm{NO}_{3}^{-}$ becomes thermodynamically the most favorable electron acceptor for the respiration of organic matter that may ultimately lead to the loss of oceanic nitrogen via denitrification or anammox (Codispoti et al., 2005; Lam and Kuypers, 2011). Upwelling was generally considered to be the only important source of $\mathrm{NO}_{3}^{-}$in these waters, whereas nitrification was considered to be of negligible significance within the oxygen-deficient OMZs. However, recent studies reported active ammonia oxidation within the eastern tropical south Pacific (ETSP) OMZ (Lam et al., 2009; Molina and Farias, 2009). Hence, a considerable portion of $\mathrm{NO}_{3}^{-}$in the OMZs may have come from recycled nitrogen. Nevertheless, the actual significance of nitrification as a $\mathrm{NO}_{3}^{-}$source in the OMZs cannot 
be fully assessed without evaluating the activities of nitrite oxidation, the second and final step of nitrification.

Direct rate measurements for nitrite oxidation in an OMZ have been reported only once (Lipschultz et al., 1990). In that study in the ETSP OMZ, nitrite oxidation rates were detected even at very low $(\leqslant 2.5 \mu \mathrm{M})$ oxygen levels. Since then, little research has been done on marine nitrite oxidation in general. Although the importance of nitrite oxidation has recently been suggested for the Arabian Sea OMZ based on a reaction diffusion model, no direct rate measurements have been made for that region (Lam et al., 2011).

Ammonia oxidation is generally presumed to be the rate-limiting step in nitrification; thereby its rates are usually taken as the overall nitrification rates (for example, Ward, 2005; Wuchter et al., 2006). In the suboxic OMZs, nonetheless, $\mathrm{NO}_{2}^{-}$can also be produced via nitrate reduction $\left(\mathrm{NO}_{3}^{-} \rightarrow \mathrm{NO}_{2}^{-}\right)$. Nitrate reduction may in theory support nitrite oxidation beyond or even in the absence of ammonia oxidation. In other words, the two steps of nitrification are not necessarily coupled in the OMZs. Meanwhile, the suboxic conditions in the OMZs also allow the occurrence of other reductive $\mathrm{NO}_{2}^{-}$-consuming processes like anammox, denitrification and dissimilatory nitrate/nitrite reduction to ammonium (DNRA) (Lam et al., 2009; Lam and Kuypers, 2011). Whether nitrite oxidation competes with these concurrent nitrogen transformations or how the overall nitrite balance may be maintained in the OMZs, remains largely unexplored.

The diversity and distribution of nitrite-oxidizing bacteria (NOB) in oceanic settings are also poorly known. Five genera of NOB have been identified so far: Nitrospira, Nitrospina, Nitrococcus, Nitrobacter and the newly discovered single-species genus Nitrotoga (Alawi et al., 2007). All genera except for Nitrotoga have been detected in marine environments, although Nitrobacter is generally not abundant in oceanic settings (Koops and PommereningRoser, 2001). Nitrospira shows a relatively widespread distribution across various habitats but few were actually marine surveys (Hoffmann et al., 2009; Off et al., 2010). Nitrococcus and Nitrospina have been found exclusively in marine habitats to date. Nitrospina appeared to be quite abundant in some open-ocean settings in the North Pacific, yet the abundance of other NOB genera was not investigated in parallel (Mincer et al., 2007; Beman et al., 2010; Santoro et al., 2010). There has been only one study to date that examined the distribution of NOB in the OMZs (Ward et al., 1989), in which only two species, Nitrobacter sp. and Nitrococcus mobilis, were targeted based on immunofluorescence. Both species were found to be present where nitrite oxidation was detected in the ETSP OMZ (Ward et al., 1989; Lipschultz et al., 1990).

In the current study, we investigated nitrite oxidation in the OMZ of the Benguela upwelling system off the Namibian coast. We optimized a method that allowed us to determine nitrite oxidation rates in the same series of ${ }^{15} \mathrm{~N}$-incubation experiments, as used for the rate measurements of other nitrogen cycling processes occurring in the OMZs. Parallel incubation experiments were conducted to evaluate for the first time the contribution of nitrite oxidation to the overall $\mathrm{NO}_{2}^{-}$turnover in OMZ waters. In particular, we compared the rates of nitrite oxidation with rates of nitrate reduction to nitrite, 'aerobic' ammonia oxidation, anammox, as well as DNRA. Moreover, we determined the abundance and distribution of all five known NOB genera by using catalyzed reporter deposition fluorescence in situ hybridization (CARD-FISH) with specific $16 \mathrm{~S}$ rRNA targeted probes.

\section{Materials and methods}

Water sampling was conducted onboard the $R / V$ Meteor in May/June 2008 (M76/2) over the Namibian shelf between $22^{\circ} 59.87^{\prime} \mathrm{S} / 14^{\circ} 3.12^{\prime} \mathrm{E}$ and $19^{\circ} 1.0^{\prime} \mathrm{S} / 12^{\circ} 13.74^{\prime} \mathrm{E}$ (Figure 1 ). Salinity, temperature, dissolved oxygen and chlorophyll $a$ fluorescence were measured with a conductivitytemperature-depth (CTD) system, equipped with an oxygen sensor and a fluorometer (Sea Bird Electronics, Bellevue, WA, USA). Oxygen data were calibrated against Winkler titration. Water samples for high-resolution vertical nutrient profiling and ${ }^{15} \mathrm{~N}$-incubation-experiments were collected with a pump-CTD system (Kuypers et al., 2003). Additionally, the benthic boundary layer (BBL) was sampled at 6 depths from $30 \mathrm{~cm}$ to $2 \mathrm{~m}$ above seafloor using a bottom water sampler (Sauter et al., 2005; Holtappels et al., 2011a). $\mathrm{NO}_{2}^{-}$and $\mathrm{NH}_{4}^{+}$ were measured on board spectrophotometrically (Grasshoff et al., 1999, detection limit $0.01 \mu \mathrm{M}$ ) and fluorometrically, respectively (Holmes et al., 1999, detection limit $0.01 \mu \mathrm{M}$ ). Water samples were frozen for later analyses of $\mathrm{NO}_{3}^{-}$and $\mathrm{PO}_{4}^{3-}$ with an autoanalyzer in a shore-based laboratory $(0.1 \mu \mathrm{M}$ detection limit; TRAACS 800, Bran \& Lubbe, Hamburg, Germany).

\footnotetext{
${ }^{15} \mathrm{~N}$-incubation experiments

Incubation experiments were conducted for 5-6 depths at 5 stations (Table 1). For each incubation experiment, a $250-\mathrm{ml}$ seawater sample was collected from specific depths with the pump-CTD system or with the bottom water sampler for samples from the BBL. Different combinations of ${ }^{15} \mathrm{~N}$ - and ${ }^{14} \mathrm{~N}$-substrates were added for the rate determinations of various nitrogen-cycling processes (Table 1). Production of ${ }^{15} \mathrm{~N}$-labeled $\mathrm{N}_{2}$ via anammox or denitrification was determined in all incubation experiments before other measurements (for further details, see Holtappels et al., 2011b). Nitrite oxidation rates were determined as the net production of
} 
a

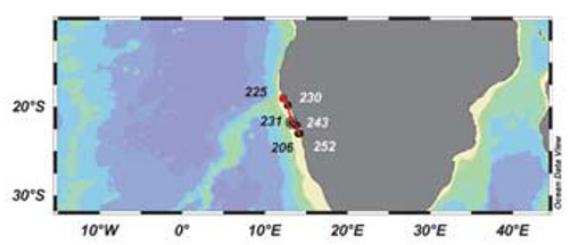

C
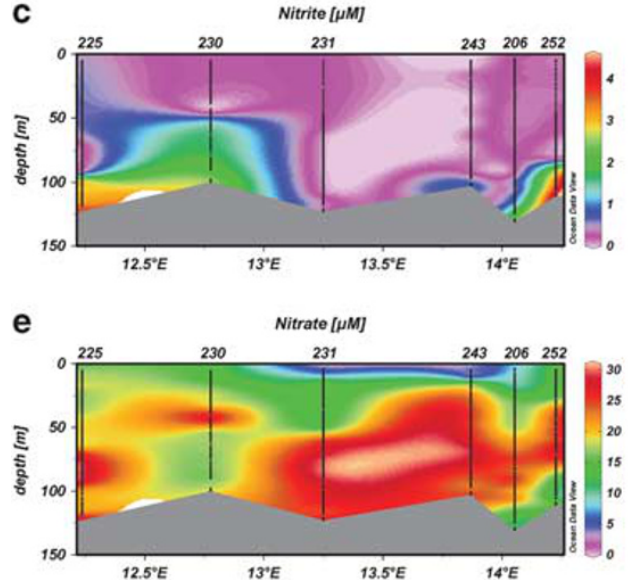

b
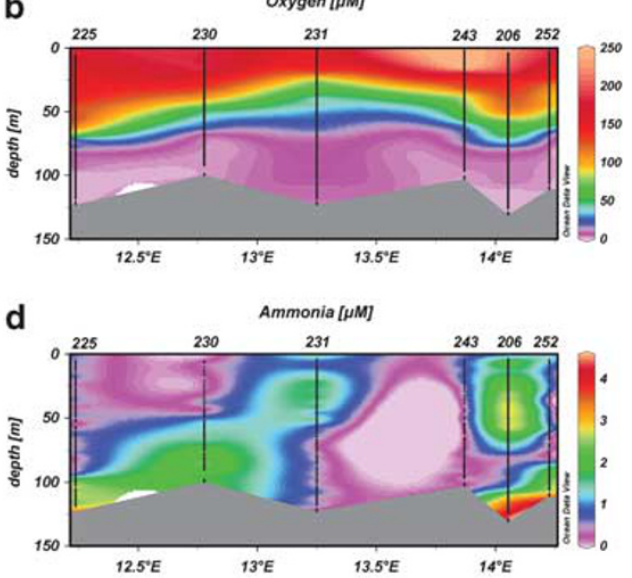

f

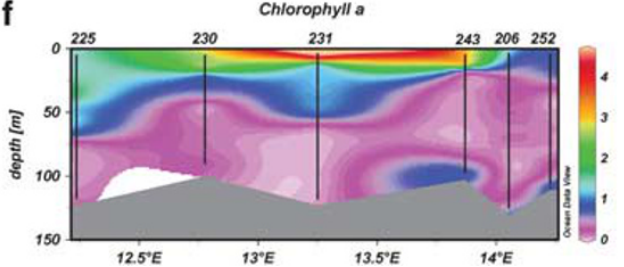

Figure 1 (a) Location of sampling stations (solid circles with station numbers) over the Namibian shelf in relation to the bathymetry of the region. The full water depths at these stations ranged between 103 and $131 \mathrm{~m}$. (b) Vertical distribution of oxygen, (c) nitrite, (d) ammonia, (e) nitrate and (f) chlorophyll $a$ (measured as fluorescence in arbitrary units, without cross calibration with absolute quantities of chlorophyll), along a NW-SE transect over the Namibian shelf. Sampling sites are indicated by black dots along the water column (the figure has been plotted with Ocean Data View (ODV) (Schlitzer, 2011)).

Table 1 Summary of stations, sampling depths and ${ }^{15} \mathrm{~N}$ incubation experiments conducted. Before the analyses for the targeted products listed, ${ }^{15} \mathrm{~N}^{15} \mathrm{~N}:{ }^{14} \mathrm{~N}^{14} \mathrm{~N}$ and ${ }^{14} \mathrm{~N}^{15} \mathrm{~N}:{ }^{14} \mathrm{~N}^{14} \mathrm{~N}$ ratios of the produced $\mathrm{N}_{2}$ were determined in all treatments in order to measure denitrification and anammox rates

\begin{tabular}{|c|c|c|c|}
\hline Station & $\begin{array}{c}\text { Bottom } \\
\text { depth }(\mathrm{m})\end{array}$ & $\begin{array}{l}\text { Sampling } \\
\text { depths (m) }\end{array}$ & $\begin{array}{c}\text { Substrate } \\
\text { additions }(\mu M)\end{array}$ \\
\hline \multirow[t]{2}{*}{206} & 131 & $\begin{array}{l}90,100,110, \\
129,130,131\end{array}$ & ${ }^{15} \mathrm{NH}_{4}^{+}(5)^{*}$, \\
\hline & & $\begin{array}{l}\mathrm{a} \\
\mathrm{a}\end{array}$ & $\begin{array}{c}{ }^{15} \mathrm{NO}_{2}^{-}(5)^{*}+\mathrm{O}_{2} \\
{ }^{15} \mathrm{NO}_{2}^{-}+{ }^{14} \mathrm{NH}_{4}^{+}(5)^{*}\end{array}$ \\
\hline \multirow[t]{3}{*}{225} & 119 & $\begin{array}{c}50,70,90, \\
117,118,119\end{array}$ & ${ }^{15} \mathrm{NH}_{4}^{+}(5)^{*}$ \\
\hline & & $\mathrm{a}$ & ${ }^{15} \mathrm{NO}_{2}^{-}(5)^{*}$ \\
\hline & & a & ${ }^{15} \mathrm{NO}_{2}^{-}+{ }^{14} \mathrm{NH}_{4}^{+}(5)^{*}$ \\
\hline \multirow[t]{4}{*}{230} & 100 & $\begin{array}{c}50,70, \\
90,98,99\end{array}$ & ${ }^{15} \mathrm{NH}_{4}^{+}(5)^{*}$ \\
\hline & & a & ${ }^{15} \mathrm{NO}_{2}^{-}(5)^{*}$ \\
\hline & & a & ${ }^{15} \mathrm{NO}_{2}^{-}+{ }^{14} \mathrm{NH}_{4}^{+}(5)^{*}$ \\
\hline & & a & ${ }^{15} \mathrm{NH}_{4}^{+}+{ }^{14} \mathrm{NO}_{2}^{-}(5)$ \\
\hline \multirow[t]{5}{*}{243} & 103 & $\begin{array}{c}80,90,97, \\
101,102,103\end{array}$ & ${ }^{15} \mathrm{NH}_{4}^{+}(5)^{*}$ \\
\hline & & a & ${ }^{15} \mathrm{NO}_{2}^{-}(5)^{*}$ \\
\hline & & a & ${ }^{15} \mathrm{NO}_{2}^{-}+{ }^{14} \mathrm{NH}_{4}^{+}(5)^{*}$ \\
\hline & & a & ${ }^{15} \mathrm{NH}_{4}^{+}+{ }^{14} \mathrm{NO}_{2}^{-}(5)$ \\
\hline & & a & ${ }^{15} \mathrm{NO}_{3}^{-}(40)+{ }^{14} \mathrm{NO}_{2}^{-}(5)$ \\
\hline \multirow[t]{5}{*}{252} & 111 & $\begin{array}{c}76,95,105, \\
109,110,111\end{array}$ & ${ }^{15} \mathrm{NH}_{4}^{+}(5)^{* \mathrm{~b}}$ \\
\hline & & a & ${ }^{15} \mathrm{NO}_{2}^{-}(5)^{*}+\mathrm{O}_{2}$ \\
\hline & & $\mathrm{a}$ & ${ }^{15} \mathrm{NO}_{2}^{-}+{ }^{14} \mathrm{NH}_{4}^{+}(5)^{*}$ \\
\hline & & a & ${ }^{15} \mathrm{NH}_{4}^{+}+{ }^{14} \mathrm{NO}_{2}^{-}$(5) \\
\hline & & a & ${ }^{15} \mathrm{NO}_{3}^{-}(40)+{ }^{14} \mathrm{NO}_{2}^{-}(5)$ \\
\hline
\end{tabular}

Asterisks $\left({ }^{*}\right)$ indicate helium-purging of the samples; 'a': same depths as listed for the treatment above, 'b': additional-oxygen manipulation experiments were conducted for this treatment.
${ }^{15} \mathrm{NO}_{3}^{-}$from ${ }^{15} \mathrm{NO}_{2}^{-}$-amended incubations. DNRA was assessed as ${ }^{15} \mathrm{NH}_{4}^{+}$production from ${ }^{15} \mathrm{NO}_{2}^{-}+{ }^{14} \mathrm{NH}_{4}^{+}$. Ammonia oxidation and nitrate reduction were measured as the production of ${ }^{15} \mathrm{NO}_{2}^{-}$from incubations with ${ }^{15} \mathrm{NH}_{4}^{+}+{ }^{14} \mathrm{NO}_{2}^{-}$and ${ }^{15} \mathrm{NO}_{3}^{-}+{ }^{14} \mathrm{NO}_{2}^{-}$, respectively. Except for the latter two, all samples were purged with helium for $15 \mathrm{~min}$ before incubations, to reduce $\mathrm{O}_{2}$ down to $\leqslant \sim 0.5 \mu \mathrm{M}$ (Dalsgaard et al., 2003; Jensen et al., 2008, 2011). To examine the effect of oxygen on $\mathrm{NO}_{2}^{-}$oxidation, additional experiments were conducted for two samples (St 206-100 $\mathrm{m}$ and St 252-105 m) with $\mathrm{O}_{2}$ adjusted to four different controlled levels $(\sim 1-11 \mu \mathrm{M})$. In these cases, a known amount of $\mathrm{O}_{2}$-saturated water was added to the He-purged samples, and the achieved $\mathrm{O}_{2}$ concentrations were checked with a microsensor or the highly sensitive switchable trace amount oxygen sensor (Revsbech et al., 2009). $\mathrm{O}_{2}$ concentrations were also monitored using the same sensors at discrete time intervals in a parallel set of incubation vials.

As described in detail in Holtappels et al. (2011b), each ${ }^{15} \mathrm{~N}\left(/{ }^{14} \mathrm{~N}\right)$-amended sample was immediately transferred into five 12-ml exetainer vials (Labco, High Wycombe, Buckinghamshire, UK), by introducing an overpressure of helium into the serum bottle such that the amended water sample was displaced via a 1-ml syringe into the bottom of each exetainer vial, which was then filled carefully from the bottom without bubbles. These samples were incubated for up to $48 \mathrm{~h}$ in the dark and at in situ temperatures. At each time interval 
(approximately 0, 6, 12, 24 and $48 \mathrm{~h}$ ), incubation was terminated in one exetainer by removing $2 \mathrm{ml}$ of sample while replacing it with helium and by adding $100 \mu \mathrm{l}$ of saturated mercuric chloride solution to stop biological activities. Samples were stored upside down in the dark at room temperature until further processing in a shore-based laboratory.

\section{Nitrite oxidation rate measurements-method optimization}

Due to the absence of a sensitive, direct method to determine nitrite oxidation rates in small-volume samples, only a limited number of field studies on this process have been performed in marine environments to date. The modified ${ }^{15} \mathrm{~N}$ stable isotope pairing technique (Nielsen and Glud 1996; Thamdrup and Dalsgaard, 2002) has successfully been applied to distinguish multiple concurrent $\mathrm{N}$ transformations in the OMZs (Lam et al., 2009). Therefore, we optimized and combined several techniques to quantify ${ }^{15} \mathrm{NO}_{3}^{-}$production in the same series of ${ }^{15} \mathrm{~N}$-incubation experiments to determine nitrite oxidation rates from incubations with ${ }^{15} \mathrm{NO}_{2}^{-}$(Table 1). To assess the $\mathrm{N}$-isotopic ratio of $\mathrm{NO}_{3}^{-}, \mathrm{NO}_{3}^{-}$first was chemically converted to $\mathrm{NO}_{2}^{-}$ and subsequently to $\mathrm{N}_{2}$ or $\mathrm{N}_{2} \mathrm{O}$, which are the forms measurable on the highly sensitive gas chromatography-isotopic ratio mass spectrometer (GC-IRMS). To distinguish the produced ${ }^{15} \mathrm{NO}_{3}^{-}$from any unused ${ }^{15} \mathrm{NO}_{2}^{-}$-amendments, the latter needs to be removed completely before the reduction of ${ }^{15} \mathrm{NO}_{3}^{-}$to ${ }^{15} \mathrm{NO}_{2}^{-}$ and the eventual conversion to $\mathrm{N}_{2}$ or $\mathrm{N}_{2} \mathrm{O}$. We tested the efficiency of sodium azide and sulfamic acid as reducing agents for $\mathrm{NO}_{2}^{-}$. Sodium azide efficiently reduces $\mathrm{NO}_{2}^{-}$to $\mathrm{N}_{2} \mathrm{O}$ (McIlvin and Altabet, 2005), but forms highly toxic gases under the acidic reaction conditions; whereas the high solubility of $\mathrm{N}_{2} \mathrm{O}$ in water hinders its complete removal. Sulfamic acid reduces $\mathrm{NO}_{2}^{-}$to $\mathrm{N}_{2}$, and has successfully been applied in analyses for the natural stable isotopic composition of $\mathrm{NO}_{3}^{-}$in seawater samples and in earlier nitrite oxidation measurements (Lipschultz et al., 1990; Granger and Sigman, 2009). Sulfamic acid is not toxic and $\mathrm{N}_{2}$ is less soluble in water than $\mathrm{N}_{2} \mathrm{O}$, thereby ensuring its efficient removal and minimizing interference with subsequent isotopic analyses for $\mathrm{NO}_{3}^{-}$. The incubation of samples with $16.5 \mathrm{mM}$ sulfamic acid (final concentration) for $\sim 12 \mathrm{~h}$ achieved better $\mathrm{NO}_{2}^{-}$removal efficiency than the reduction with azide, and so became our method of choice for subsequent nitrite oxidation rate measurements (Supplementary Figure S1). Following $\mathrm{NO}_{2}^{-}$removal, sample $\mathrm{pH}$ was adjusted to $8-9$ and spongy cadmium was added to $6 \mathrm{ml}$ of experimental subsamples in order to reduce $\mathrm{NO}_{3}^{-}$to $\mathrm{NO}_{2}^{-}$ (Margeson et al., 1980; McIlvin and Altabet, 2005). They were then incubated for at least $12 \mathrm{~h}$ on a horizontal shaker at room temperature (Gal et al., 2004). Subsequently, samples were transferred to fresh $6 \mathrm{ml}$ exetainers with $2 \mathrm{ml}$ headspace and flushed with helium for $10 \mathrm{~min}$ to remove any $\mathrm{N}_{2}$ produced from ${ }^{15} \mathrm{NO}_{2}^{-}$. Finally, the $\mathrm{NO}_{2}^{-}$converted from $\mathrm{NO}_{3}^{-}$via cadmium was further reduced to $\mathrm{N}_{2}$ by the addition of sulfamic acid as previously described, and the samples were neutralized with $\mathrm{NaOH}$ afterwards. The resultant $\mathrm{N}_{2}$ was then ready for isotopic analyses.

\section{Stable isotopic analyses of $\mathrm{N}_{2}$ and $\mathrm{N}_{2} \mathrm{O}$}

Nitrogen stable isotopic ratios of $\mathrm{N}_{2}$ and $\mathrm{N}_{2} \mathrm{O}$ were determined by GC-IRMS (VG Optima, Manchester, UK). Before any chemical conversions to determine the $\mathrm{N}$-isotopic compositions of nitrite, nitrate or ammonium, the ${ }^{15} \mathrm{~N}^{15} \mathrm{~N}:{ }^{14} \mathrm{~N}^{14} \mathrm{~N}$ and ${ }^{15} \mathrm{~N}^{14} \mathrm{~N}:{ }^{14} \mathrm{~N}^{14} \mathrm{~N}$ ratios of $\mathrm{N}_{2}$ produced via denitrification and/or anammox were measured in all treatments. Ammonia oxidation rates and nitrate reduction rates were determined as the ${ }^{15} \mathrm{NO}_{2}^{-}$production over time from ${ }^{15} \mathrm{NH}_{4}^{+}\left(+{ }^{14} \mathrm{NO}_{2}^{-}\right)$and ${ }^{15} \mathrm{NO}_{3}^{-}\left(+{ }^{14} \mathrm{NO}_{2}^{-}\right)$, respectively, via the reduction of $\mathrm{NO}_{2}^{-}$by sodium azide to $\mathrm{N}_{2} \mathrm{O}$ for GC-IRMS analyses (McIlvin and Altabet, 2005). To determine DNRA rates, the $\mathrm{N}$-isotopic composition of $\mathrm{NH}_{4}^{+}$was determined in $5 \mathrm{ml}$ subsamples $(+5 \mu \mathrm{M}$ added ${ }^{14} \mathrm{NH}_{4}^{+}$) by converting $\mathrm{NH}_{4}^{+}$to $\mathrm{N}_{2}$ with hypobromite (Warembourg, 1993; Lam et al., 2009). Rates of all processes were calculated from the slopes of linear regression with ${ }^{15} \mathrm{~N}$-production as a function of time, and only when the production was instantaneous (Supplementary Figure S3). All rates presented were calculated from $0-48 \mathrm{~h}$ of incubations $(P<0.05)$, except for a few samples in which there was no more substantial nitrate production after $12 \mathrm{~h}$ likely because nitrite was depleted. All rates reported here were calculated as net rates, and have been corrected for the ${ }^{15} \mathrm{~N}$-labeling percentages of initial substrate pools. However, in incubation experiments for the rate determination of DNRA, ammonia oxidation and nitrate reduction, the addition of unlabeled $\left({ }^{14} \mathrm{~N}\right)$ 'products' $\mathrm{NH}_{4}^{+}, \mathrm{NO}_{2}^{-}$and $\mathrm{NO}_{2}^{-}$, respectively, alongside ${ }^{15} \mathrm{~N}$-labeled substrates would likely have minimized immediate consumption of the ${ }^{15} \mathrm{~N}$-labeled products during the incubation period. Hence, these measured rates are expected to be closer to gross rates.

\section{Catalyzed reporter deposition in situ fluorescence hybridization}

Water samples for CARD-FISH were fixed in $2 \%$ (final concentration) paraformaldehyde in phosphate buffered saline solution for $8-12 \mathrm{~h}$ at $4{ }^{\circ} \mathrm{C}$, before filtration onto polycarbonate membrane filters (GTTP, $0.22 \mu \mathrm{M}$ pore size, $47 \mathrm{~mm}$ diameter, Millipore, Eschborn, Germany). CARD-FISH was performed following the protocol by Pernthaler et al., (2002). Briefly, cells were immobilized on the GTTP filters by embedding in $0.2 \%$ agarose. Then, cells were permeabilized by $60 \mathrm{~min}$ incubation at $37^{\circ} \mathrm{C}$ in $10 \mathrm{mg} \mathrm{ml}^{-1}$ lysozyme in $50 \mathrm{mM}$ EDTA and $100 \mathrm{~mm}$ Tris-HCl. Hybridization with horseradish peroxidase labelled oligonucleotide probes 
Table 2 NOB specific 16S rRNA targeted oligonucleotide probes and the respective formamide concentrations in the hybridization buffer applied in this study

\begin{tabular}{|c|c|c|c|c|}
\hline Probe & Sequence $\left(5^{\prime} \rightarrow 3^{\prime}\right)$ & formamide (\%) & Species & Source \\
\hline Ntcoc-84 & TCGCCAGCCACCTTTCCG & 20 & Nitrococcus mobilis & Juretschko (2000) \\
\hline Ntspn-693 & TTCCCAATATCAACGCATTT & 20 & Nitrospina gracilis & Juretschko (2000) \\
\hline Ntspa-662 & GGAATTCCGCGCTCCTCT & 35 & Nitrospira spp. & Daims et al. (2001) \\
\hline NIT3 & CCTGTGCTCCATGCTCCG & 40 & Nitrobacter spp. & Wagner et al., (1996) \\
\hline Ntoga122 & TCCGGGTACGTTCCGATAT & 40 & Nitrotoga $s p$. & Luecker, 2010 \\
\hline FGall178 & TCCCCCTYAGGGCATATG & 30 & Gallionellaceae & Luecker, 2010 \\
\hline
\end{tabular}

Abbreviation: NOB, nitrite-oxidizing bacteria.

(Biomers, Ulm, Germany) was conducted for $2 \mathrm{~h}$ at $46{ }^{\circ} \mathrm{C}$ at varying formamide concentrations, according to the oligonucleotide applied (Table 2). This was followed by tyramide signal amplification for 15 min at $46^{\circ} \mathrm{C}$ and subsequent staining of cells with DAPI (4, 6-diamidino-2-phenylindole). Positive hybridization signals and DAPI-stained cells were enumerated with epifluorescence microscopy (Axioplan 2, Zeiss, Jena, Germany).

\section{Results and discussion}

Hydrochemical setting of the Namibian OMZ

All five stations investigated in this study were located over the Namibian shelf from $19^{\circ} \mathrm{S}$ to $23^{\circ} \mathrm{S}$, with bottom depths ranging between 103 and $130 \mathrm{~m}$ (Figure 1). They were generally characterized by high primary production in the euphotic zone as indicated by the high surface chlorophyll $a$ concentrations (Figure 1f). Dissolved oxygen concentrations in surface waters were in the range of $170-245 \mu \mathrm{M}$, and declined to $\leqslant 4 \mu \mathrm{M}$ by $80-90 \mathrm{~m}$ water depth (Figure 1b). At most stations investigated, prominent $\mathrm{NO}_{2}^{-}$and $\mathrm{NH}_{4}^{+}$maxima of up to 4.4 and $4.6 \mu \mathrm{M}$, respectively, were present in the lower OMZ; whereas $\mathrm{NO}_{3}^{-}$concentrations showed a reverse trend with local minima as low as $12 \mu \mathrm{M}$ within the OMZ (Figures 1c-e).

\section{Nitrite oxidation rates}

Nitrite oxidation rates were detected at all five stations investigated, at depths spanning from the oxycline to the BBL (Figure 2, Supplementary Figure S2). The measured rates ranged from 14 to $372 \mathrm{nM} \mathrm{d}^{-1}$ (Figure 2). These values were within the range of previous observations from the ETSP OMZ, where maximum rates reached $\sim 170-600 \mathrm{nM} \mathrm{d}^{-1}$ at 4 different stations (Lipschultz et al., 1990). No systematic trends could be discerned with respect to depth or oxygen availability in our dataset, with some stations exhibiting maximum nitrite oxidation rates in the lower OMZ (for example, St 252) and some in the BBL (for example, St 225; Figure 2). At other stations, nitrite oxidation decreased with water depth (Station 243) or was not detectable in the BBL (St 206) (Supplementary Figure S2).

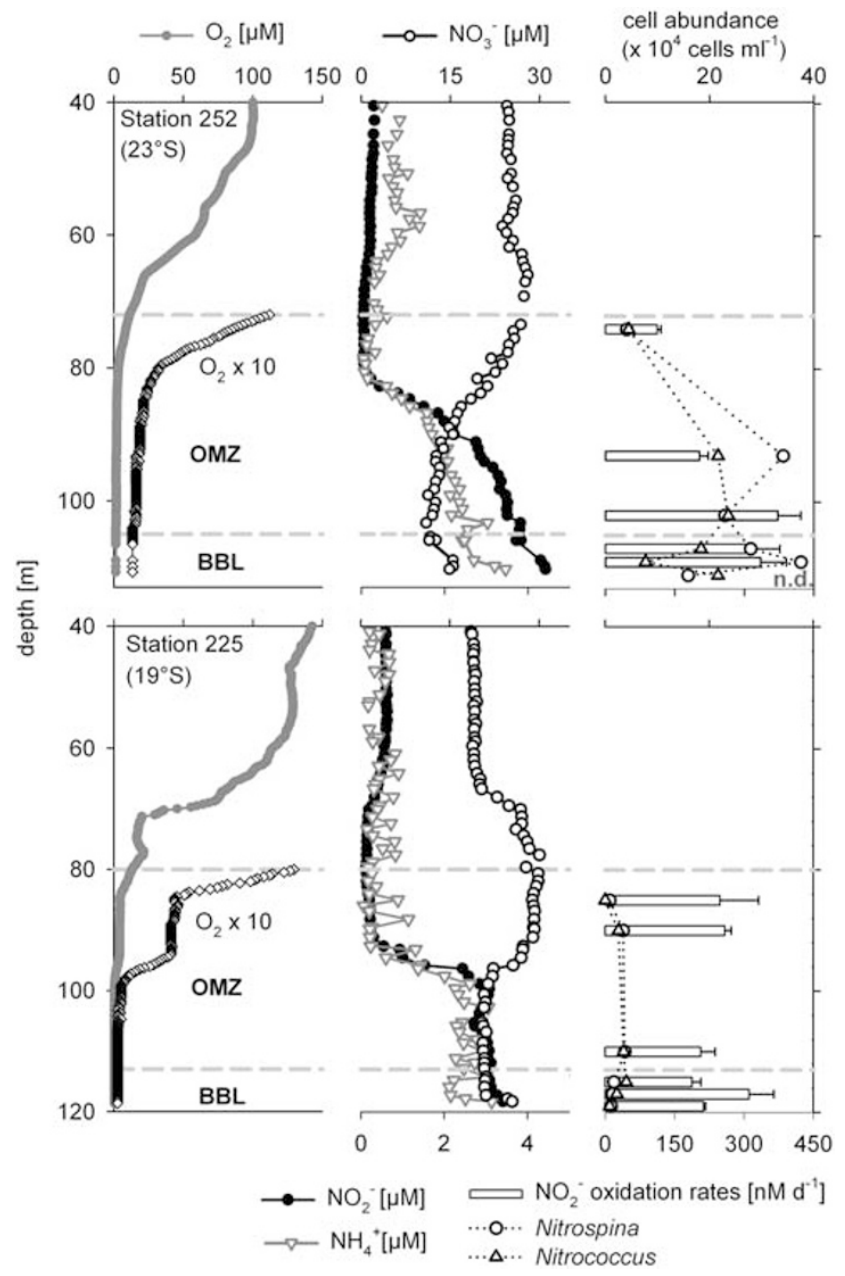

Figure 2 Stations 252 and 225: High-resolution vertical profiles of oxygen and $10 \times$ its concentration in the OMZ and BBL $\left(\mathrm{O}_{2}\right.$ gray circles, $\mathrm{O}_{2} \times 10$ open diamonds) (left panels) and of nutrients ( $\mathrm{NO}_{2}^{-}$, black solid circles; $\mathrm{NH}_{4}^{+}$, gray triangles; $\mathrm{NO}_{3}^{-}$, open circles) (central panels). $\mathrm{NO}_{2}^{-}$oxidation rates measured as ${ }^{15} \mathrm{NO}_{3}^{-}$production are indicated by horizontal bars (right panels). At each depth, cellular abundance of Nitrococcus (triangle) and Nitrospina (circle) are shown. Most nitrite oxidation rates presented are derived from significant slopes $(P<0.05)$ in corresponding linear regression. On occasions, ${ }^{15} \mathrm{NO}_{3}^{-}$was produced so rapidly that a maximum was reached within as little as $\sim 12 \mathrm{~h}$, therefore rates were calculated only from these first $12 \mathrm{~h}$. Despite their substantial and instantaneous ${ }^{15} \mathrm{NO}_{3}^{-}$production and the apparently high correlation between ${ }^{15} \mathrm{NO}_{3}^{-}$and time $\left(r^{2}>0.90\right)$, the low degrees of freedom resulted in slightly higher $P$-values $(0.07-0.20)$ from one-way ANOVA in a few experiments-St 225: $85 \mathrm{~m}$ and $118 \mathrm{~m}$; St 252: 105, 109 and $110.7 \mathrm{~m}$. 'n.d.' denotes non-detectable reaction rates. 

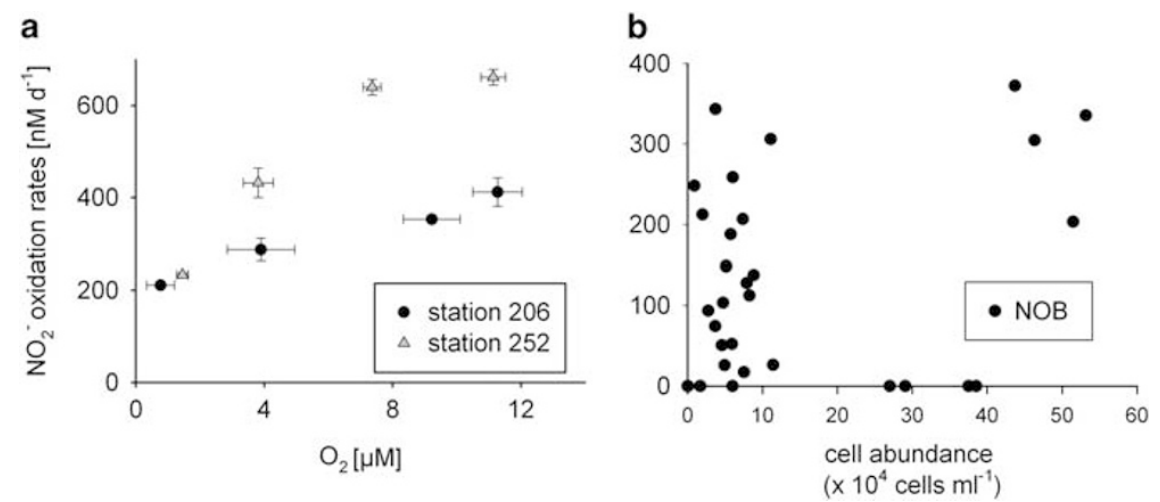

Figure 3 (a) Influence of $\mathrm{O}_{2}$ concentration on nitrite oxidation: ${ }^{15} \mathrm{NO}_{3}^{-}$production rates were determined in incubations with various controlled $\mathrm{O}_{2}$ levels in two water samples-station 206 at $100 \mathrm{~m}$ and station 252 at $105 \mathrm{~m}$. (b) NOB abundance as detected with $16 \mathrm{~S}$ rRNAbased CARD-FISH in relation to the measured nitrite oxidation rates.

Interestingly, the highest rates observed during this study $\left(372 \pm 45 \mathrm{nM} \mathrm{d}^{-1}\right.$ at St 252 and $343 \pm 40 \mathrm{nM} \mathrm{d}^{-1}$ at St 225) seemed to occur at very low $\mathrm{O}_{2}$ levels $(<1 \mu \mathrm{M})$ in the lower OMZ and the BBL, respectively (Figure 2). As these rates were in fact determined in helium-purged water samples, in which oxygen had been reduced down to $\leqslant \sim 0.5 \mu \mathrm{M}$ as verified in the current and previous studies with microsensors (Dalsgaard et al., 2003; Jensen et al., 2008, 2011), our results showed that nitrite oxidation occurred at microaerobic or apparently anoxic conditions. The effect of $\mathrm{O}_{2}$ on nitrite oxidation was further examined in ${ }^{15} \mathrm{~N}$-labeling experiments with varying $\mathrm{O}_{2}$ concentrations $(0-11 \mu \mathrm{M})$ in the Namibian OMZ waters. Although nitrite oxidation rates were 1-2 fold higher under elevated $\mathrm{O}_{2}$ levels $(\leqslant 11.3 \mu \mathrm{M}$; Figure 3), considerable nitrite oxidation rates were measured in incubations where $\mathrm{O}_{2}$ levels were close to detection limit or at levels equivalent to ambient conditions. Similar observations of high nitrite oxidation rates associated with low $\mathrm{O}_{2}(\leqslant 2.5 \mu \mathrm{M})$ have also been reported for the ETSP OMZ (Lipschultz et al., 1990). Therefore, nitrite-oxidizing communities in the OMZs appear to be well adapted to oxygen-deficient conditions.

Nitrite availability or competition for nitrite with other processes might affect nitrite oxidation rates in the OMZ. Although the highest nitrite oxidation rates in this study were obtained from the $\mathrm{NO}_{2}^{-}$ maxima at stations 225 and 252 (Figures 1 and 2), there appeared to be no correlation between $\mathrm{NO}_{2}^{-}$ availability and nitrite oxidation rates when considering the entire dataset (Supplementary Figure S4). However, we cannot fully exclude the possibility of activity stimulation by the amendment of $5 \mu \mathrm{M}$ of ${ }^{15} \mathrm{NO}_{2}^{-}$in samples containing low (that is, nanomolar) $\mathrm{NO}_{2}^{-}$concentrations. To identify the exact mode of rate regulation on nitrite oxidation, further sampling and experimentation in higher spatial and temporal resolution are necessary, including manipulative experiments with variable substrate levels to examine the kinetics of nitrite oxidation. Regardless, the current dataset shows that nitrite oxidation occurred at substantial rates throughout the Namibian OMZ.

\section{$N O B$ in the Namibian $O M Z$}

The abundance of potential NOB in the Namibian OMZ waters was assessed via 16S rRNA-based CARD-FISH, targeting all NOB genera known to date (Nitrobacter, Nitrococcus, Nitrospira, Nitrotoga and Nitrospina). Among these genera, only Nitrospina and Nitrococcus were detectable in the samples investigated. These NOB were abundant throughout the Namibian OMZ, indicating that these genera might substantially contribute to the measured nitrite oxidation rates in these waters (Figure 2, Supplementary Figure S2). Nitrospina and Nitrococcus constituted up to $5.4 \%$ and $4.9 \%$ of total microbial abundance, respectively. Together, these two NOB genera represented $0.3-9 \%$ of total microbial community, equivalent to $0.09-5.5 \times 10^{5} \mathrm{cells} \mathrm{ml}^{-1}$. In general, the NOB abundance in the present study was several orders of magnitude higher than that reported in an ETSP OMZ study, in which a maximum of $1.1 \times 10^{3}$ cells ml $\mathrm{ml}^{-1}$ were detected with immunofluorescence (Ward et al., 1989). The applied antisera in the latter study had been produced against few cultured strains, which might thus be too specific to cover all NOB species present in the environment and resulted in underestimation. Our results are within the same range as those found in the central Californian current, where up to $1 \times 10^{4}$ 16S rRNA gene copies per $\mathrm{ml}$ of the genus Nitrospina were detected by quantitative PCR, yet other NOB genera were not targeted in that study (Santoro et al., 2010).

Although the highest nitrite oxidation rates measured during this study corresponded well with the highest NOB abundance $\left(4.37 \times 10^{5}\right.$ and $5.32 \times 10^{5}$ cells ml $^{-1}$ at $105 \mathrm{~m}$ and $1.12 \mathrm{~m}$ above seafloor, respectively, at St 252), NOB abundance did not show a significant correlation with nitrite oxidation rates (Spearman rank correlation, $P>0.05$; 


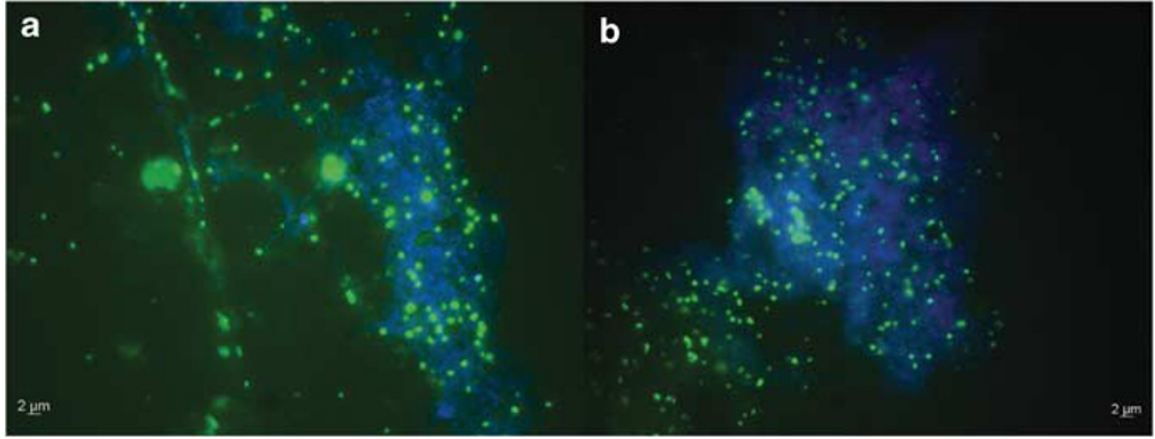

Figure 4 Epifluorescence micrographs showing dense populations of Nitrospina (green) (a) and Nitrococcus (green) (b) cells in large aggregates with other microorganisms (blue) at station 206 in $110 \mathrm{~m}$ water depth, as detected with 16S rRNA-based CARD-FISH.

Figure 3b). The oligonucleotide probes used in our CARD-FISH analyses should in theory cover all NOB genera available in public databases, but diversity surveys for marine nitrite oxidizers have been few so that these probes may not cover all NOB species in nature. In addition, dense populations of both Nitrococcus and Nitrospina cells were sometimes observed in large aggregates $(\leqslant 250 \mu \mathrm{m}$ wide) with other microorganisms (Figures $4 \mathrm{a}$ and b). Consequently, NOB were difficult to enumerate in such cases and their abundance was likely underestimated at those depths. These factors might partly explain the lack of clear correlation in samples where nitrite oxidizer abundance was relatively low while nitrite oxidation rates were high. At the same time, NOB abundance was sometimes found to be high, although nitrite oxidation activities were barely or not detectable (Figure 3b). These NOBs might be using an alternative pathway to gain energy. Regardless, the combination of molecular and biogeochemical results obtained in the current study provides strong evidence for the importance of NOB for N-cycling in the Namibian OMZ.

\section{Decoupling of nitrite oxidation from ammonia} oxidation

Ammonia oxidation and nitrite oxidation are regarded as successive steps in nitrification, with ammonia oxidation being the first and presumably rate-limiting step. Therefore, ammonia oxidation rates should in principle be as high as nitrite oxidation rates. Ammonia oxidation rates were compared with nitrite oxidation rates at three stations for which measurements for both processes were available at the same depths (Figure 5, Supplementary Figure S2). Nitrite oxidation often exceeded ammonia oxidation by as much as two- to three-folds, except for some depths at station 243, where ammonia oxidation rates were higher instead (Figure 5, Supplementary Figure S2). Although ammonia oxidation experiments were conducted in unpurged samples whereas nitrite oxidation experimental subsamples were He-purged, parallel-oxygen sensitivity experiments indicate that ammonia oxidation rates remained unchanged from purged to unpurged samples and up to $12 \mu \mathrm{M} \mathrm{O} \mathrm{O}_{2}$ (Kalvelage et al., in press). Similarly, nitrite oxidation rates were found to be several-fold greater than ammonia oxidation rates in the ETSP OMZ, based on the ${ }^{15} \mathrm{~N}$-tracer method (Lipschultz et al. 1990). Results from both OMZs show that both nitrification processes were actively recycling significant proportions of nitrogen back to the $\mathrm{NO}_{3}^{-}$pool in the OMZs. However, the two reactions were not necessarily coupled, as the measured ammonia oxidation could not provide sufficient $\mathrm{NO}_{2}^{-}$to support the detected nitrite oxidation rates. Therefore, another source of $\mathrm{NO}_{2}^{-}$was required for nitrite oxidation.

Nitrate reduction to $\mathrm{NO}_{2}^{-}$, although often regarded as the first step in denitrification, also occurs as an independent reaction. It has been found as an important process in the ETSP and Arabian Sea OMZ (Lipschultz et al., 1990; Lam et al., 2009, 2011). Nitrate reduction rates were measured at two stations in our study (St 243 and 252). Active nitrate reduction was detected throughout the OMZ, at rates of $17-469 \mathrm{nM} \mathrm{d}^{-1}$ (Figure 5). Nitrate reduction rates exceeded ammonia oxidation rates by one- to three- fold at St 252. At this station, nitrate reduction could provide up to $325 \%$ of the $\mathrm{NO}_{2}^{-}$ consumed in nitrite oxidation and up to $100 \%$ of total $\mathrm{NO}_{2}^{-}$production. Ammonia oxidation alone produced less than $\sim 60 \%$ of the $\mathrm{NO}_{2}^{-}$required by nitrite oxidation at station 252. Meanwhile, ammonia oxidation at St 243 was responsible for 35-74\% of total $\mathrm{NO}_{2}^{-}$production, whereas the contribution from nitrate reduction was generally lower (26-66\%) (Figure 5). In other words, both ammonia oxidation and nitrate reduction were important $\mathrm{NO}_{2}^{-}$ sources for nitrite oxidation in the Namibian OMZ. On the basis of these results, nitrification should not be regarded as one single process, but rather as two independent reactions, at least in suboxic settings similar to the OMZs.

Competition with other nitrite-consuming processes Nitrite can be consumed by nitrite oxidation, anammox, denitrification and DNRA. The occurrence of DNRA 


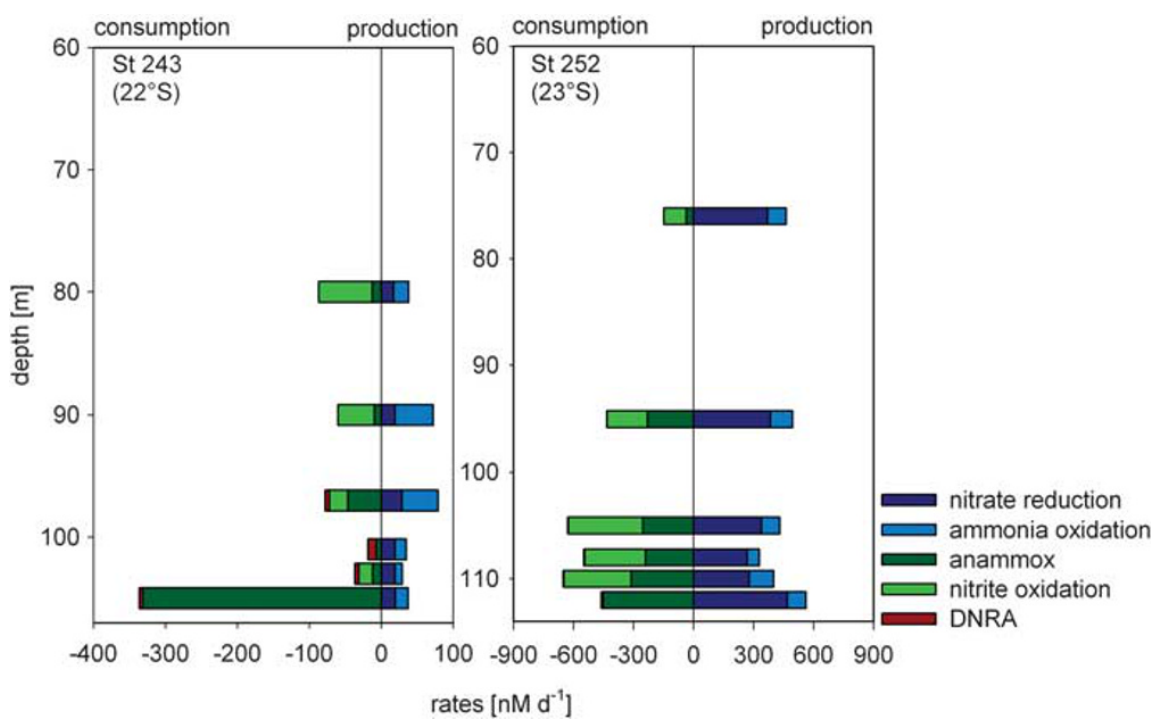

Figure 5 Comparison of nitrite sources and sinks at stations 243 and 252. Rates of $\mathrm{NO}_{2}^{-}$consuming processes, include anammox (dark green), nitrite oxidation (light green) and DNRA (red). $\mathrm{NO}_{2}^{-}$producing processes, include ammonia oxidation (light blue) and nitrate reduction (dark blue). The rates were determined from parallel incubation experiments that have been conducted with the same set of samples. Most rates presented are derived from significant slopes $(P<0.05)$ in corresponding linear regression. On occasions, ${ }^{15} \mathrm{NO}_{3}^{-} /{ }^{15} \mathrm{NO}_{2}^{-}$was produced so rapidly that a maximum was reached within as little as $\sim 12 \mathrm{~h}$, so rates were calculated only from these first $12 \mathrm{~h}$. Despite their substantial and instantaneous ${ }^{15} \mathrm{NO}_{3}^{-} /{ }^{15} \mathrm{NO}_{2}^{-}$production and the apparently high correlation between ${ }^{15} \mathrm{NO}_{3}^{-} /{ }^{15} \mathrm{NO}_{2}^{-}$and time $\left(r^{2}>0.90\right)$, the low degrees of freedom resulted in slightly higher $P$-values $(0.07-0.20)$ from one-way ANOVA in a few experiments-Nitrite oxidation: St 243: 97m; St 252: 105, 109 and 110.7 m; Nitrate reduction: St 252, 76 and 109 m. 'n.d.' denotes non-detectable reaction rates.

has been reported from the Namibian OMZ, but actual rates were not determined (Kartal et al., 2007). In this study, DNRA rates were determined at five stations, but significant rates were measurable only at few depths (Figure 5). They never exceeded $10 \mathrm{nM} \mathrm{d}^{-1}$ and were usually 1-2 orders of magnitude lower than anammox and nitrite oxidation. Therefore, DNRA did not appear to be an important nitrite sink in the Namibian OMZ, at least at the time and location of our sampling. However, DNRA might become more important during more prolonged anoxia such that the true significance of DNRA in the OMZ remains to be further explored.

Previous investigations with ${ }^{15} \mathrm{~N}$-labelling experiments revealed high rates of anammox in the Namibian OMZ, whereas denitrification was only detected in the presence of sulfide (Kuypers et al., 2005; Lavik et al., 2009). In the current study, only low denitrification rates were detected at two bottommost BBL samples $(\sim 30 \mathrm{~cm}$ above the sediment) at stations 206 and 231,but sulfide was not measurable (data not shown). Overall, anammox was the main $\mathrm{N}_{2}$-producing process at all investigated stations at the time of our sampling (Figure 2, Supplementary Figure S2). Anammox occurred at almost all depths where nitrite oxidation rates were determined, whereas nitrite oxidation rates often exceeded anammox rates.

When all $\mathrm{NO}_{2}^{-}$sources and sinks are compared, there was roughly a nitrite balance within the middepths of the OMZ, where nitrite concentration was at its lowest (Figure 5). Net $\mathrm{NO}_{2}^{-}$consumption was calculated usually for depths closest to the seafloor where $\mathrm{NO}_{2}^{-}$levels were highest. However, the presented crude nitrite budget (Figure 5) has not taken into account any external inputs and outputs. As BBLs are characterized by intense turbulent mixing and sharp gradient of nutrients (for example, Holtappels et al., 2011a), additional $\mathrm{NO}_{2}^{-}$could have been provided by the underlying sediments at these depths. Nitrite might also be transported laterally by both cross-shelf and along-shelf currents (Lass and Mohrholz, 2005). To fully assess the true nitrite and nitrogen budget in the Namibian OMZ, both water circulation and sediment-water fluxes need to be taken into consideration.

\section{Conclusions}

The optimized method to determine nitrite oxidation rates in seawater presented in this study enables us to directly measure low nitrite oxidation rates from small-volume samples used in ${ }^{15} \mathrm{~N}$-incubation experiments. This method has allowed us for the first time to quantitatively assess the role of nitrite oxidation in the nitrogen cycle of the Namibian OMZ. The ${ }^{15} \mathrm{~N}$-incubation experiments revealed the occurrence of nitrite oxidation throughout the Namibian OMZ. Even in the apparent absence of oxygen, nitrite oxidation proceeded at significant rates, indicating either microaerobic activities of nitrite-oxidizers or the occurrence of anaerobic nitrite oxidation. The exact use of electron acceptors in such conditions remains to be determined. 
Nitrospina and Nitrococcus were abundant throughout the Namibian OMZ, indicating that these genera might have substantially contributed to the measured nitrite oxidation rates in these waters. However, the low abundance of these NOB at depths where high rates of nitrite oxidation were measured, suggested that more organisms were involved in nitrite oxidation in the Namibian OMZ. On the other hand, where the cell densities were too high to be explained by the determined rates, these NOB might have gained energy from processes other than nitrite oxidation.

Nitrite oxidation rates often exceeded ammonia oxidation rates, such that the two steps of nitrification are not necessarily coupled within the OMZ. Nitrate reduction, on the other hand, served as an alternative and significant $\mathrm{NO}_{2}^{-}$source under these suboxic conditions. Nitrite oxidation and anammox co-occurred in these oxygen-deficient waters, with NOB potentially competing with anammox bacteria for $\mathrm{NO}_{2}^{-}$when this substrate becomes limiting.

Our combined results indicate that a considerable fraction of the recently recycled nitrogen or reduced $\mathrm{NO}_{3}^{-}$was re-oxidized back to $\mathrm{NO}_{3}^{-}$by nitrite oxidation. Hence, NOB in oxygen-deficient waters may play a critical role in the global $\mathrm{N}$-cycle, potentially diminishing the amount of N-loss from OMZs.

\section{Acknowledgements}

We sincerely thank cruise leader Kay Emeis (University of Hamburg) and the crew of the $R / V$ Meteor (cruise M 76/2) for their support at sea. We are grateful for the conscientious technical and analytical assistance of Gabriele Klockgether, Daniela Franzke, Tim Kalvelage, Jan Fischer, Andreas Ellrott and Volker Meyer (Max Planck Institute for Marine Microbiology). Funding came from the Max Planck Gesellschaft and Deutsche Forschungsgemeinschaft (for Meteor cruise M76/2).

\section{References}

Alawi M, Lipski A, Sanders T, Eva Maria P, Spieck E. (2007). Cultivation of a novel cold-adapted nitrite oxidizing betaproteobacterium from the Siberian Arctic. ISME J 1: 256-264.

Beman JM, Sachdeva R, Fuhrman JA. (2010). Population ecology of nitrifying archaea and bacteria in the southern California bight. Environ Microbiol 12: 1282-1292.

Codispoti LA, Yoshinari T, Devol AH. (2005). Suboxic respiration in the oceanic water column. In: Giorgio $\mathrm{P}$ del, Williams PJ LeB (eds). Respiration in Aquatic Ecosystems. Oxford University Press: Oxford, pp 225-247.

Daims H, Nielsen JL, Nielsen PH, Schleifer KH, Wagner M. (2001). In situ characterization of Nitrospira-like nitrite oxidizing bacteria active in wastewater treatment plants. Appl Environ Microbiol 67: 5273-5284.

Dalsgaard T, Canfield DE, Petersen J, Thamdrup B, AcunaGonzalez J. (2003). N-2 production by the anammox reaction in the anoxic water column of Golfo Dulce, Costa Rica. Nature 422: 606-608.

Gal C, Frenzel W, Moller J. (2004). Re-examination of the cadmium reduction method and optimisation of conditions for the determination of nitrate by flow injection analysis. Microchim Acta 146: 155-164.

Granger J, Sigman DM. (2009). Removal of nitrite with sulfamic acid for nitrate $\mathrm{N}$ and $\mathrm{O}$ isotope analysis with the denitrifier method. Rapid Commun Mass Spectrom 23: 3753-3762.

Grasshoff K, Ehrhardt M, Kremling K. (1999). In: Methods of Seawater Analysis. Basel Verlag Chemie: Basel.

Gruber N. (2004). The dynamics of the marine nitrogen cycle and its influence on atmospheric $\mathrm{CO} 2$ variations. In: Follows M, Oguz T (eds). The Ocean Carbon Cycle and Climate, NATO ASI Series. Kluwer Academic: Dordrecht, pp 97-148.

Hoffmann F, Radax R, Woebken D, Holtappels M, Lavik G, Rapp HT et al. (2009). Complex nitrogen cycling in the sponge Geodia barretti. Environ Microbiol 11: 2228-2243.

Holmes RM, Aminot A, Kerouel R, Hooker BA, Peterson BJ. (1999). A simple and precise method for measuring ammonium in marine and freshwater ecosystems. Can J Fish Aquat Sci 56: 1801-1808.

Holtappels M, Kuypers MMM, Schlüter M, Brüchert V. (2011a). Measurement and interpretation of solute concentration gradients in the benthic boundary layer. Limnol Oceanogr Meth 9: 1-13.

Holtappels M, Lavik G, Jensen MM, Kuypers MMM. (2011b). ${ }^{15} \mathrm{~N}$-labelling experiments to dissect the contribution of heterotrophic denitrification and anammox to nitrogen removal in the OMZ waters of the ocean. Meth Enzymol 486(Part A): 223-251.

Jensen MM, Kuypers MMM, Lavik G, Thamdrup B. (2008). Rates and regulation of anaerobic ammonium oxidation and denitrification in the Black Sea. Limnol Oceanogr 53: $23-36$.

Jensen MM, Lam P, Revsbech NP, Nagel B, Gaye B, Jetten MSM et al. (2011). Intensive nitrogen loss over the Omani Shelf due to anammox coupled with dissimilatory nitrite reduction to ammonium. ISME J 5: $1660-1670$.

Juretschko S. (2000). Mikrobielle Populationsstruktur und -dynamik in einernitrifizierenden/denitrifizierenden Belebtschlammanlage. PhD Dissertation, Department for Microbiology, Technical University Munich.

Kalvelage T, Jensen MM, Contreras S, Revsbech NP, Lam P, Günter $\mathrm{M}$ et al. (2011). Oxygen sensitivity of anammox and coupled $\mathrm{N}$-cycle processes in OxygenMinimum Zones. PLoS One (in press).

Kartal B, Kuypers MMM, Lavik G, Schalk J, den Camp H, Jetten MSM et al. (2007). Anammox bacteria disguised as denitrifiers: nitrate reduction to dinitrogen gas via nitrite and ammonium. Environ Microbiol 9: 635-642.

Koops HP, Pommerening-Roser A. (2001). Distribution and ecophysiology of the nitrifying bacteria emphasizing cultured species. Fems Microbiol Ecol 37: 1-9.

Kuypers MMM, Lavik G, Woebken D, Schmid M, Fuchs BM, Amann R et al. (2005). Massive nitrogen loss from the Benguela upwelling system through anaerobic ammonium oxidation. Proc Natl Acad Sci USA 102: 6478-6483. 
Kuypers MMM, Sliekers AO, Lavik G, Schmid M, Jorgensen BB, Kuenen JG et al. (2003). Anaerobic ammonium oxidation by anammox bacteria in the Black Sea. Nature 422: 608-611.

Lam P, Jensen MM, Kock A, Bange HW, Lettmann KA, Plancherel $\mathrm{Y}$ et al. (2011). Origin and fate of the secondary nitrite maximum in the Arabian Sea. Biogeosci Discuss 8: 2357-2402.

Lam P, Kuypers MM. (2011). Microbial nitrogen cycling processes in oxygen minimum zones. Ann Rev Mar Sci 3: 317-345.

Lam P, Lavik G, Jensen MM, van de Vossenberg J, Schmid M, Woebken D et al. (2009). Revising the nitrogen cycle in the Peruvian oxygen minimum zone. Proc Natl Acad Sci USA 106: 4752-4757.

Lass HU, Mohrholz V. (2005). On the fluctuations and vertical structure of the shelf circulation off Walvis Bay, Namibia. Continental Shelf Res 25: 1473-1497.

Lavik G, Stuhrmann T, Bruchert V, Van der Plas A, Mohrholz V, Lam P et al. (2009). Detoxification of sulphidic African shelf waters by blooming chemolithotrophs. Nature 457: 581-U586.

Lipschultz F, Wofsy SC, Ward BB, Codispoti LA, Friedrich G, Elkins JW. (1990). Bacterial transformations of inorganic nitrogen in the oxygen-deficient waters of the eastern tropical South-Pacific ocean. Deep-Sea Res Part A Oceanogr Res Papers 37: 1513-1541.

Luecker S. (2010). Exploring the ecology and genomics of globally important nitrite-oxidizing bacteria. Dissertation, University of Vienna.

Margeson JH, Suggs JC, Midgett MR. (1980). Reduction of nitrate to nitrite with cadmium. Anal Chem 52: 1955-1957.

McIlvin MR, Altabet MA. (2005). Chemical conversion of nitrate and nitrite to nitrous oxide for nitrogen and oxygen isotopic analysis in freshwater and seawater. Anal Chem 77: 5589-5595.

Mincer TJ, Church MJ, Taylor LT, Preston C, Kar DM, DeLong EF. (2007). Quantitative distribution of presumptive archaeal and bacterial nitrifiers in Monterey Bay and the North Pacific Subtropical Gyre. Environ Microbiol 9: 1162-1175.

Molina V, Farias L. (2009). Aerobic ammonium oxidation in the oxycline and oxygen minimum zone of the eastern tropical South Pacific off northern Chile (similar to 20 degrees S). Deep-Sea Res Part II Top Stud Oceanogr 56: 1009-1018.
Nielsen LP, Glud RN. (1996). Denitrification in a coastal sediment measured in situ by the nitrogen isotope pairing technique applied to a benthic flux chamber. Mar Ecol Progr Ser 137: 181-186.

Off S, Alawi M, Spieck E. (2010). Enrichment and physiological characterization of a novel Nitrospiralike bacterium obtained from a marine sponge. Appl Environ Microbiol 76: 4640-4646.

Pernthaler A, Pernthaler J, Amann R. (2002). Fluorescence in situ hybridization and catalyzed reporter deposition for the identification of marine bacteria. Appl Environ Microbiol 68: 3094-3101.

Revsbech NP, Larsen LH, Gundersen J, Dalsgaard T, Ulloa O, Thamdrup B. (2009). Determination of ultra-low oxygen concentrations in oxygen minimum zones by the STOX sensor. Limnol Oceanogr Methods 7: $371-381$.

Santoro AE, Casciotti KL, Francis CA. (2010). Activity, abundance and diversity of nitrifying archaea and bacteria in the central California Current. Environ Microbiol 12: 1989-2006.

Sauter EJ, Schluter M, Wegner J, Labahn E. (2005). A routine device for high resolution bottom water sampling. J Sea Res 54: 204-210.

Schlitzer R. (2011). Ocean Data View. http://odv.awi.de.

Thamdrup B, Dalsgaard T. (2002). Production of N-2 through anaerobic ammonium oxidation coupled to nitrate reduction in marine sediments. Appl Environ Microbiol 68: 1312-1318.

Wagner M, Rath G, Koops HP, Flood J, Amann R. (1996). In situ analysis of nitrifying bacteria in sewage treatment plants. Water Sci Technol 34: 237-244.

Ward BB, Glover HE, Lipschultz F. (1989). Chemoautotrophic activity and nitrificatiion in the oxygen minimum zone off Peru. Deep-Sea Res Part A Oceanogr Res Papers 36: 1031-1051.

Ward BB. (2005). Temporal variability in nitrification rates and related biogeochemical factors in Monterey Bay, California, USA. Mar Ecol Progr Ser 292: 97-109.

Warembourg FR (1993). Nitrogen fixation in soil and plant systems. In: Knowles K, Blackburn TH (eds). Nitrogen Isotopes Techniques. Academic Press: New York, pp 157-180.

Wuchter C, Abbas B, Coolen MJL, Herfort L, van Bleijswijk $\mathrm{J}$, Timmers $\mathrm{P}$ et al. (2006). Archaeal nitrification in the ocean. Proc Natl Acad Sci USA 103: $12317-12322$.

Supplementary Information accompanies the paper on The ISME Journal website (http://www.nature.com/ismej) 